Discussion: The most commonly used translation decision as to the German compound noun Torschlusspanik while rendered by the lexeme fear into English is somewhat irrelevant since Torschlusspanik in German is a kind of the particular fear represented by the word Angst. A deeper study of the nature of the emotional notions denoted in German by lexemes Angst, Furcht, Befürchtung and Panik, and in English by angst, fear, anxiety and panic is the basis that makes it possible to determine such pairs of partial equivalents as (full equivalence is not worth speaking about): Furcht $\approx$ fear; Befürchtung $\approx$ fear; Panik $\approx$ panic; Angst $\approx$ angst / anxiety.

Keywords: translation, translation mistake, emotion, emotional notion, corpus-based methodology.

\title{
Vitae
}

Kostiantyn Mizin is Doctor of Philology, Professor, Head of Department of Foreign Philology, Translation and Teaching Methodology, SHEI "Pereiaslav-Khmelnytskyi Hryhorii Skovoroda State Pedagogical University". His areas of research interests include contrastive linguoculturology, phraseology, contrastive conceptology, cognitive linguistics, contrastive linguistics.

Correspondence: kmizin@i.ua

Надійшла до редакції 25 березня 2021 року Рекомендована до друку 8 квітня 2021 року

Ганна Ситар

ORCID: orcid.org 0000-0001-8806-8322

Анастасія Мартинович (Вдовиченко)

ORCID: orcid.org 0000-0002-5254-470X

DOI 10.31558/1815-3070.2021.41.35

УДК 811.161.2'28'33(477.44):004.416.6

\section{ЕКСПЕРТНА СИСТЕМА АНАЛІЗУ МОВЛЕННЯ МЕШКАНЦІВ МІСТА ГНІВАНЬ: ДОСВІД СТВОРЕННЯ}

Запропоновано лінгвістичну частину експертної системи аналізу діалектного мовлення, описано етапи ї̈ створення. Виділено фонетичні та морфологічні риси говірки міста Гнівань Тиврівського району Вінницької області. Схарактеризовано процес створення словника говірки. Подано опис основних компонентів експертної системи аналізу мовлення мешканиів міста Гнівань.

Ключові слова: аналіз мовлення, говірка, діалект, експертна система, прикладна лінгвістика, словник.

Постановка проблеми та їі актуальність. Експертні системи є одним із важливих напрямів досліджень у межах штучного інтелекту, вони мають великий потенціал для вирішення різних практичних завдань, у тому числі у сфері аналізу мови та мовлення.

На сучасному етапі розвитку штучного інтелекту створюють різні програми для аналізу літературної мови. Однак, цього, на жаль, ще не можна сказати про українське діалектне мовлення, що є одним із найцінніших джерел для вивчення динамічних процесів у мові. Тому створення експертної системи аналізу мовлення мешканців міста Гнівань $\epsilon$ важливим кроком у застосуванні підходів штучного інтелекту для вивчення діалектного мовлення.

Аналіз досліджень. Експертна система - це комп'ютерна програма, що оперує знаннями в певній предметній галузі для створення рекомендацій або для розв'язання відповідних проблем (Джексон 2001: 12). Вона покликана частково замінити собою людину-фахівця, 
відігравати роль асистента, експерта. Ця технологія спрямована на те, щоб емулювати ті аспекти діяльності людини, які вимагають мислення й досвіду.

Експертна система містить знання фахівців у вигляді бази знань, що складається 3 множини фактів і набору взаємопов'язаних правил (Gupta, Nagpal 2020; Liebowitz 2019; Частиков, Гаврилова, Белов 2003 та ін.). Це дає змогу аналізувати наслідки різних рішень на кшталт запитань «Що буде, якщо...» й не витрачати часу на кропіткий процес програмування.

У лінгвістиці експертні системи використовують для розв'язання таких важливих проблем, як розпізнавання мовлення, навчання мови, ідентифікація мовця, створення програмперекладачів, комп'ютерних словників і под. (Вдовиченко 2020). Серед відомих екпертних систем можна назвати Hearsay-II, TLCTS (Tactical language and culture training systems), Izhora та ін.

Мета цього дослідження - створити лінгвістичну частину експертної системи аналізу діалектного мовлення мешканців міста Гнівань Тиврівського району Вінницької області.

Для досягнення поставленої мети розв'язано такі завдання: 1) зроблено цифрові записи мовлення носіїв говірки зазначеного населеного пункту, записано їх фонетичною транскрипцією; 2) охарактеризовано фонетичні риси говірки міста Гнівань; 3) виділено морфологічні риси досліджуваної говірки; 4) створено електронний словник обстежуваної говірки; 5) визначено та описано етапи створення експертної системи аналізу мовлення мешканців міста Гнівань.

Об’єктом дослідження $є$ мовлення мешканців міста Гнівань Тиврівського району Вінницької області.

Предметом дослідження $є$ фонетичні, морфологічні й лексичні особливості мовлення мешканців міста Гнівань, що є підгрунтям для створення експертної системи.

Матеріалом дослідження є аудіозаписи мовлення 7 жителів міста Гнівань віком від 54 до 83 років, носіїв місцевої говірки, які мають нормальний слух, добре мовне чуття, не мають фізичних вад у мовному апараті й мовлення яких порівняно мало зазнало впливу української літературної мови.

Під час дослідження використано такі методи: аналізу, синтезу, моделювання, описовий і структурний (зокрема, прийом компонентного аналізу і прийом дистрибутивного аналізу).

Наукова новизна праці полягає в тому, що вперше створена експертна система аналізу мовлення носіїв говірки міста Гнівань Вінницької області.

Практичне значення. Основні положення дослідження й результати можуть бути використані для створення експертних систем аналізу мовлення інших говірок, для укладання словника подільських говірок, а також під час викладання навчальних дисциплін «Українська діалектологія», «Прикладна лінгвістика», «Лінгвістичне моделювання» здобувачам вищої освіти спеціальності 035 Філологія.

Викладення основного матеріалу й обгрунтування результатів дослідження. За класифікацією говорів української мови й за картами говорів, говірка міста Гнівань належить до південно-західного наріччя, волинсько-подільської групи його діалектів, а саме до подільського говору, північноподільських говірок (Атлас української мови 1984, Бевзенко 1980 та ін.); межує з говірками волинського говору південно-західного наріччя й говірками середньонаддніпрянського говору південно-східного наріччя, тому логічно припустити, що в досліджуваній говірці наявні не тільки мовні явища, характерні загалом для говору чи групи говірок, до яких територіально належить обстежувана говірка, а можуть існувати в сусідніх говірках.

Створення лінгвістичної частини для експертної системи передбачає формалізацію особливостей мовлення мешканців міста Гнівань й охоплює три етапи: 1) формалізація фонетичних рис; 2) формалізація морфологічних рис; 3) укладання словника говірки.

Перший етап. Формалізація фонетичних рис

На першому етапі для подальшої формалізації потрібно виділити 3-поміж фонетичних рис говірки міста Гнівань ті, що:

- притаманні літературній мові й говірці міста Гнівань; 
- відмінні від літературної мови (діалектні) риси (докладно про особливості підсистем голосних і приголосних у говірці міста Гнівань див. (Вдовиченко 2017; Вдовиченко 2018а)).

\section{Фонетичні риси, які притаманні літературній мові та говірці міста Гнівань:}

1) Майже послідовне вживання [i] на місці давнього *ъ. Фонема /i/ в цьому випадку виступає незалежно від наголосу: зал'ізу, д'іточки́.

2) На місці давніх *o, *е, що опинилися в історично закритих чи в так званих новозакритих складах, уживається [i], а у відкритих складах [o], [е] зберігаються (чергування [o], [е] 3 [i]): n'iч, с'm'iл.

3) Фонема $\mid$ и $\mid$ в наголошеній позиції в говірці міста Гнівань реалізується в основному своєму вияві [и] переднього ряду високого піднесення з дещо обниженою артикуляцією в напрямку до середнього ряду: холоди́л'ник, мали́на.

4) Ненаголошені [и] та [е] в ненаголошеній позиції зближуються й виступають у звуках

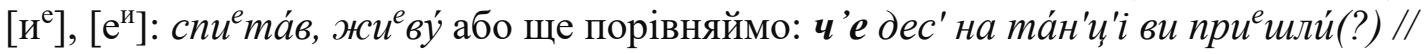

5) Фонема $|\mathrm{e}|$ в наголошеній позиції переважно виступає як звук переднього ряду середнього піднесення [е], не набираючи відтінку іншого звука пе́рше, јаблуне́вий.

6) Фонема $|y|$ виступає в основному своєму вияві, як лабіалізований звук заднього ряду високого піднесення [у] відповідно до давніх *у(и) та *๑(Ж): мýxa.

7) Фонема $|\mathrm{o}|$ в наголошеній позиції виступає в говірці міста Гнівань як звук [о], тобто як лабіалізований звук заднього ряду середнього піднесення: n’iшо́в.

8) Фонема $|\mathrm{a}|$ виступає як нелабіалізований звук заднього ряду низького піднесення [a]: ха́ma, га́рна.

9) Фонеми $|3|,|c|$ реалізуються в основних своїх виявах [3], [c], а також у звукових варіантах [3'], [c'], що залежить від характеру наступного звука: в 'iз'ми, вчивс'a.

10) Тверді фонеми $|ж|,|ш|$ ([ж] [ш]) виступають у своєму основному вияві перед голосними

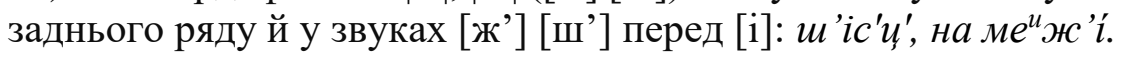

11) Африката $\mid$ ц' | звичайно реалізується в основному своєму вияві [ц']: u̧'iнýje.

12) Фонеми |л|, |н| у досліджуваній говірці реалізуються в основних своїх виявах [л], [н] та у звукових варіантах [л'], [н'], причому варіанти [л'], [н'] звичайно виступають у всіх словах у позиції перед [i] (<‡, е) або перед м'яким приголосним: л'і́то, л'і́вий, н'ic, d'н'a.

13) Уживання [ри], [ли] збігається з літературною нормою: криева́вий, глиета́ти.

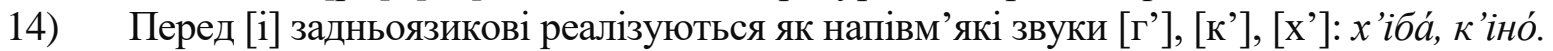

Фонетичні риси говірки міста Гнівань, відмінні від літературної мови:

1) Унаслідок гармонійної асиміляції [i] може переходити в [у], що спостерігається перед складом з [у], наприклад, у словах иілувати, дірка, діра: и'улува́ти, и'улу́й, д'ýрка, д'ура́

2) У багатьох словах замість [i] виступає [e] з попереднім пом'якшенням приголосного. Це пояснюється впливом російської мови: пожие ли́й був д'ед.

3) У досліджуваній говірці трапляються й випадки відхилення в чергуванні [o], [е] 3 [i]: то вони по́мн'ат' / шо в n'ijic'ám'i рока́ / n'ijic'ám'i / сороков'ї рока́ / до войни́ $i$ n'íc'л'а войни́ // 4) Характерною собливістю обстежуваної говірки є й заміна [i] на [и] в позиції після [к], [г] (частіше протетичних): та й меи не́ хиета́је ра́зом с ти́ми гил'а́ками //

5) Замість [и] після твердого приголосного виступає [i] після пом'якшеного: xто б'і́mе

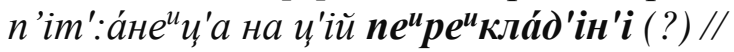

6) У ненаголошеній позиції фонема $|\mathrm{e}|$ може реалізуватися не тільки як звуки $\left[\mathrm{e}^{ }\right],\left[\mathrm{u}^{\mathrm{e}}\right]$, а виявлятися як [и]: приейшо́в на гру́n’i $i$ ле́дви жиевим веирну́вс'а ч’ýдом //

7) Перед складами 3 наголошеними [и], [i], [у] ненаголошений [е] зазнає більшого звуження і сильніше зближується з [и]: мо́жсиш бйти / бий / m'íки не дра́nаŭ/ бо мин'і́ всти́дно ду́же //

8) У деяких словах у позиції перед [i], а також після [j], ненаголошений [е] набирає сильного відтінку [i] чи й зовсім звучить як [i]: захова́jiмc'a / а в’ін до ма́ми ж⿻ал'йіiu'a //

9) Заступлення [е] звуком [i] може відбуватися і в інших позиціях: оч'кú в н'о́zо на p’iз 'і́нках / а тр'ін'ірува́тис' на́да / не сач'кува́ти на́да // 
10) У слові глибокий замість [и] зафіксовано [i]: гл'ібо́кий.

11) У ненаголошеній позиції наявне помірне або сильне «укання» (звук [о] наближається до [0 $\left.{ }^{\mathrm{y}}\right]$ ) або [у]): збо́ку вони́ сид'і́ли / $і$ ичей / де н'ікул'ука́ то́ше ставо́к //

12) Поширене чергування [о] з нулем звука: napm'ija захт'іла //

13) Зрідка зафіксовано помірне «акання» у вимові слів іншомовного походження: ко нфоо́рка, ко тлава́н, кро ва́m'.

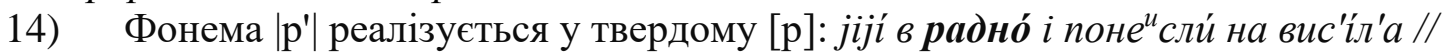

15) У досліджуваній говірці фонема звукосполучення [хв] нерідко заступається звуком [ф]: ф’'іст, ф'ірткка.

16) Сполука «губний + |j|» змінена на сполуки [мн'], [бл'], [вл']: так са́мо було́ обовл'аско́во на napám пройmúc'a //

17) У говірці м. Гнівань зафіксоване асимілятивне перетворення [вн]>[мн]: p’iмний, р'імн'ати.

18) Нерідко дзвінкі приголосні оглушуються в кінці слова: на с'о́ме жо́вт'н'а був napám // одно́го ро́ку то таки́ моро́c //

19) Оглушення може бути і в середині слова з іншими асимілятивними змінами: по́мн'y в моло́чших кла́сах вчи́лис'а //

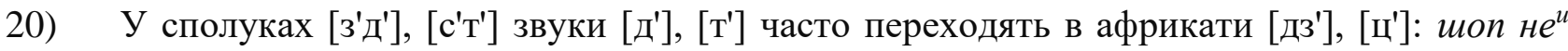
змокр'ілли с'из'іни //

21) У звукосполученні [дц'] звук [д] унаслідок регресивної асиміляції переходить у [ц'], а в результаті подальших змін сполука [ц'ц'] нерідко перетворюється на [ц'] або [ц]: двана́ц'im', триена́uзиm'.

22) У формах 3-ої особи дієслів теперішнього часу приголосний [т] звичайно твердий: одну́ дв 'i в 'із'мý / та й знов корти́m//

23) Спостерігається ствердіння [c'], а також [3'], [ц'] у звукосполуках [с'к], [3'к], [ц'к], що виступають у прикметникових суфіксах -ский, -зкий: апре́л'ска па́ска, по́л'ске кла́дб'ішч'е.

24) Напівм'які [ж'], [ш'] виступають переважно перед [i] $(<$ b, е). У називному та знахідному відмінках однини іменників середнього роду перед закінченням - $a$ (n'idн'iж: $a$, роздор'їс:a) й -y в орудному відмінку однини іменників III відміни фонеми [ж], [ш] вимовляються твердо: по́дорож:у, ро́ск'iш:y.

25) В обстежуваній говірці відсутнє чергування [3] // [ж] та [c] // [ш]: во́з'y, но́с'y, а також чергування [т] // [ч] у дієсловах: колот'ý соб'í чай / а вона́ dúве u'a //

26) Значно рідше використовується [дж]. У дієслівних формах 1-ої особи однини теперішнього часу типу ходжу, воджу на місці [дж] уживається [д'] або [ж] (у мовленні жителів молодшого віку): хо́жу, бужу́, сижу́; а ја хо́d'y на робо́ту в су́тки на апарату́рниц̆ в дв'i зм'іни //

27) У багатьох словах спостерігається й заступлення африкат [дз], [дз'] відповідними фрикативними свистячими [3], [3']: зе́ркало, зво́ние к, зв'ін, кукуру́за.

28) Характерним явищем є так зване «шокання», тобто заміна у вимові [шч] на [ш]: $a$ шо $m$ јак ја jix бáy'y / m'iŭ хóчеu u̧'a.

29) Трапляються випадки вживання м'якого [р'] перед $a$ (коли зникає у вимові [j]): a caм ja йду че́ре ${ }^{u}$ с колго́сn/ че́ре $e^{u}$ подв'íp'a //

30) Слово криниця побутує в аналізованій говірці як кирни́щ̧'а (керни́u'a).

31) Для говірки міста Гнівань характерне вживання фонеми [г] замість [г]: ганок, грати, гвалт.

32) В іменниках І відміни в давальному та місцевому відмінках однини чергування [г], [к], [х] зі свистячими [3'], [ц'], [c'] порушується повністю чи частково, через що в говірці

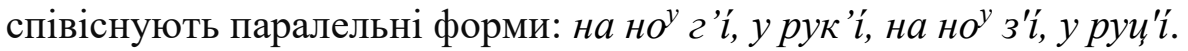

33) Поширений протетичний [г]: го́ко, гора́ти, го б 'і́ати.

34) Відсутність подвоєння (подовження) м'яких приголосних: ну таке́ ж⿻ит'á / jак оби́чне //

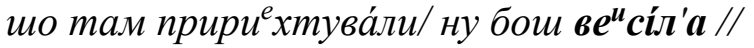


35) Випадіння окремих звуків або групи звуків у середині слова (явище синкопи (кáe (каже), бо́e (боже), мо́на (можна), то́е (тоже), вс'оре́мја (всьо врем'я)), наприкінці слова (явище апокопи (тре (треба), хоч (хочеш)): а в'ін јі́де мопе́диеком / m'iй ка́e / о тут до́бр'i уч'ін'іки // н'е ка́у не ива́ла // ну вони́ то́е кури́ли / а ја ше не всп'ів // а ч'о не так / не так / бо коту́ n’im хв 'icm // так $і$ за́ра вну́ч'ка моја́ по де ре́вах ла́зе / так са́мо л'у́бе // в гн'і́ван'i шос' тре купи́ти //

36) Наявність у деяких словах явища метатези: було́ назбиера́jу гоіркі́в //

37) Опускання [j] у позиції після голосного: то вже вс'і обра́дувалиес' / мо цее знашли́ л'уди́ну / i було́ с'm'ілл'ки кло́n'imy // ну вс'о вже тод'í / приешо́в / вже бра́ли корова́й д'івча́та //

38) Фонема $\mid$ и| в деяких словах після шиплячих реалізується як [i] 3 попереднім пом'якшенням шиплячого: ч'ій (чий).

\section{Другий етап. Формалізація морфологічних рис}

На другому етапі для формалізації морфологічних особливостей говірки потрібно розмежувати також на дві групи:

- притаманні літературній мові й говірці міста Гнівань;

- відмінні від літературної мови, тобто діалектні риси.

\section{Морфологічні риси говірці міста Гнівань, що збігаються 3 літературними:}

1. Морфологічна категорія роду має типову для норм української літературної мови репрезентацію.

2. Категорія числа реалізована двома числовими формами - одниною та множиною.

3. У називному відмінку однини прикметники чоловічого роду мають, як і в літературній мові, флексії -ий (для твердої групи) та -ій (для м'якої групи).

4. $\quad$ У мовленні зафіксовано чимало прикметників зі зменшено-пестливим значенням.

Морфологічні риси говірки міста Гнівань, відмінні від літературної мови:

1) Трапляються випадки хитання категорії роду в іменниках чоловічого й жіночого роду: л'icanému не ма́ла / н'їде н'іч'ó //

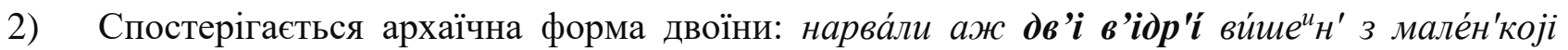

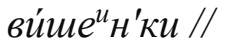

3) У називному відмінку однини іменники II відміни середнього роду на - $a$ найчастіше

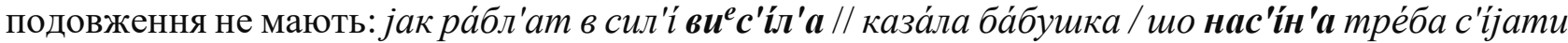
в те́плу зе́мл'у //

4) У родовому відмінку однини чимало іменників чоловічого роду, що в літературній мові мають закінчення - $a$, у говірці виступають із закінченням -y: в н'о́zо не було́ докуме́нту про шко́лу / m'іŭ не п'ішо́в н'іку́ди / до́ки не довчи́вс'а ше р'ік // або навпаки цее проб'і́хтис' на́да mydú / ųe de за́рас в кин'ų'í го́рода //

5) Спостерігаються поодинокі випадки архаїчних форм уживання іменників III відміни із закінченням -и: л'убо́ви, зло́сти.

6) Флексія -ом виступає в іменниках середнього роду на - $a$ II i IV відмін: з това́ришом ходиӯ за фе́рму куритти //

7) В іменниках середнього роду II відміни (назвах неістот), окрім закінчення -y в давальному відмінку та закінчення -i в місцевому використовується флексія -ові: ка́е на со́нц'ові не сиди́ / бо згори́ш //

8) Іменники середнього роду IV відміни в місцевому відмінку мають закінчення -y, -ові (-еві) та вживаються переважно в безсуфіксних формах: зра́зу неи дава́ли тел'о́ві са́ти / тро́ха n'iзн'і́шче //

9) У кличному відмінку поширеними є усічені форми: Окса́н / ко́тика не

10) Незмінювані іменники іншомовного походження змінюються в досліджуваній говірці: 8 кин'і́ тани'ува́ли бага́то й сп'іва́ли //

11) Часте вживання демінутивних іменників із зменшено-пестливими суфіксами: пото́м вс'i на пара́т ме́н'ш'i с ша́р'іками / кв 'іточ 'ка́ми //

12) У досліджуваній говірці трапляються нечленні якісні прикметники (у формах називного та знахідного відмінків), а також короткі форми присвійних прикметників набувають вигляду 


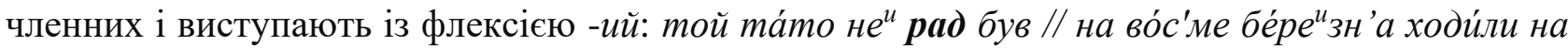
д'ám'ковий ден' наро́джен'а //

13) У творенні ступенів порівняння прикметників знаходимо теж низку особливостей: вищий ступінь порівняння твориться за допомогою суфіксів -ч-, -ішч-: ста́рший бли́шче /

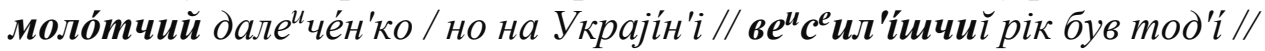

14) Форми найвищого ступеня здебільшого аналітичні: творяться шляхом додавання слова самий до форми вищого ступеня: там вро́д'i би були са́м 'i крупн'і́шч ’i / вкус'н'їшч i //

15) Чимало прикметників утворюється за допомогою суфікса -ов- замість -ев-: була́ ра́да / јак ма́ма купи́ла за́мшов’i кánu̧'i //

16) Числівники сорок, дев'яносто, сто в родовому відмінку здебільшого мають закінчення таке саме, як і в називному відмінку, а в орудному часто вживаються у формах, відмінних від літературної мови: бабу́с'а в ме́не ду́же до́вго жиела́ / до дивино́сто двух ро́к'ів // сорокома / дев'яностома / стома //

17) Зрідка спостерігаються архаїчні форми особових займенників: у него, до него, а також відносно-питальний займенник що (або похідні від нього) виступає в різновиді шо: но ка́е / встава́й в строй або шо не́буд' //

18) У непрямих відмінках займенника цุей (оцей) кореневий голосний [e] зберігається, не заступаючись голосним [o]: б’іzали / шука́ли вс'ýdu / i пото́м вже i на подв 'íp'i шука́ли $i$ на це́емy //

19) Використання форм родового відмінка займенника III особи однини вона в давальному або місцевому відмінках однини: т'ій вже завјаза́ли јijí хусти́нку / там јаку́ там ма́је //

20) Займенник все завжди вживається як всьо: $і$ иче вс'о ду́же га́рно засте́лено //

21) Окрім форм інфінітива на -mu, часто можна простежити й форму на -mb: $x m o$ не $e^{u} x о m^{\prime} \bar{y}^{-}$ роби́m' в колго́сn'i / того́ забиера́ли //

22) Дієслово лити в 1, 2, 3 особах однини та множини теперішнього часу (а також у деяких формах минулого та майбутнього часу) виступає у специфічній формі: дошч’ ли́je / јак 3 в’idpá //

23) У дієсловах 3 особи однини II дієвідміни замість закінчення -ить виступає флексія $е$ : так $i$ за́ра вну́ч'ка моја́ по дере́вах ла́зе //

24) У формах дієслів 1 особи множини майже завжди фіксуємо скорочені закінчення -им, -ем замість -имо, -емо, а при відмінюванні дієслів архаїчної групи дати, їсти в II особі однини маємо

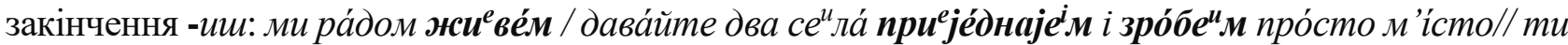
даси́ш ме и'і́ тра́хтора / шоб горо́д згора́ти (?)//

25) Дієслова умовного способу, які закінчуються на голосний, здебільшого вживаються 3 часткою би: п'iшла́ би ја ӯ к’iнó / ma гро́ш'ів не мй //

26) У мовленні побутують пасивні дієприкметники, причому досить поширеними $є$ форми із суфіксом -ан-, що відповідає літературному -ен-: л'і́кко соло́моју посте́л'ане //

27) В іменниках множинної форми в родовому відмінку часто простежується флексія -iв: ja ка́y тв 'ій ко́тик ме не́ три́ста гри́вн'ів сто́јав // а јакра́с јак Вита́ва та́ко дв 'і суше́йна і та ву́лиц'а

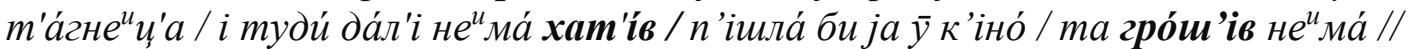

28) Інколи носії говірки не диференціюють м’яку й тверду групи прикметників: каза́в Анто́н пок'ійний / це јого́ двојуір 'id'н'ій брат //

29) Функціонування різних форм вказівних займенників: изейго, оцеево, оцего, оцеей, оия, оціi, ота, отой, ото, оте, отіо, иеейг, ияя, иегго, цеггой, отаго, тойго та ін.: а в 'ін до ма́ми жа́л'іјеи'а / ма́ма на н'у насва́риц'а / ну таке́ було́// а там в сил'і́ де тий париехха́хер'і колис' ше були / бе ру́m цего́ / кру́m'am d’л'а моло́дојі ку́чер’i // отаки́й був за́тишний в них д'ім / на горбо́ч'ку // таки́й с'н'іг отакиго́ //

30) Займенник 3 особи однини в знахідному відмінку однини зрідка має давню усічену форму н'y: ба́ба Фра́н'а подиеви́лас'а на н'y і сказала / шо роди́лас'а нив 'і́стка // 
31) Поширені усічені форми займенників: а та́mо / јак мало́jу / прúŭде з робо́ти / тай знájy / шо н'iч'ó тако́ не ку́nе / бо стро́jiлис'а / ва́шко було́ // а не зна́ју / чого́ в інн боја́вс'а / но боја́вс'а / а ја н'iч'ó не боја́лас'а //

\section{Третій етап. Укладання словника говірки міста Гнівань}

Лексичні особливості мовлення мешканців міста Гнівані відбито у вигляді словника, створеного на основі записів мовлення та їх транскрипції. На сьогодні цей словник налічує 2513 лексичних одиниць. Для створення словника було використано дві офісні програми MS Word та MS Exel. Цей процес охопив декілька кроків (Ситар, Вдовиченко 2020):

1) видалення «/», пробілів, розташування кожного слова в окремий рядок;

2) видалення порожніх рядків;

3) сортування слів за абеткою;

4) копіювання отриманого списку слів у MS Exel у стовбець «Транскрипція діалектного слова», видалення повторів;

5) добирання літературних відповідників до отриманих слів говірки; цю процедуру виконано на основі академічних словників української мови (СУМ 1970-1980, СУМ 20102020); результати оформлено у стовбець «Літературний відповідник».

Опис створеної експертної системи. Програмну реалізацію запропонованих у дослідженні формалізації фонетичних i морфологічних рис говірки міста Гнівань, а також укладеного словника гніванської говірки здійснив студент факультету інформаційних і прикладних технологій ДонНУ імені Василя Стуса Сергій Орлов у межах виконання дослідження під керівництвом старшого викладача кафедри прикладної математики О.С. Вєтрова. Програма написана мовою C++, інтерфейс користувача створено за допомогою Framework QT 5. Вона призначена для роботи на персональних комп'ютерах зі встановленою операційною системою Windows.

Як матеріал для створення експертної системи було взято відомості про місто Гнівань, виділені на попередніх етапах дослідження фонетичні та морфологічні риси говірки, укладений словник.

Створена експертна система виконує такі функції:

- забезпечує доступ до інформації, яка зберігається в базі даних програми;

- виводить інформацію з баз даних;

- здійснює навігацію вкладками програми;

- перетворює діалектне транскрибоване речення на літературне;

- перетворює літературний запис на діалектний транскрибований;

- виводить словник з діалектним словом і його літературним відповідником.

Під час запуску програми користувач може побачити вікно експертної системи, яке містить такі вкладки (рис. 1):

- аналізатор;

- морфологічні риси;

- фонетичні риси;

- історія міста.

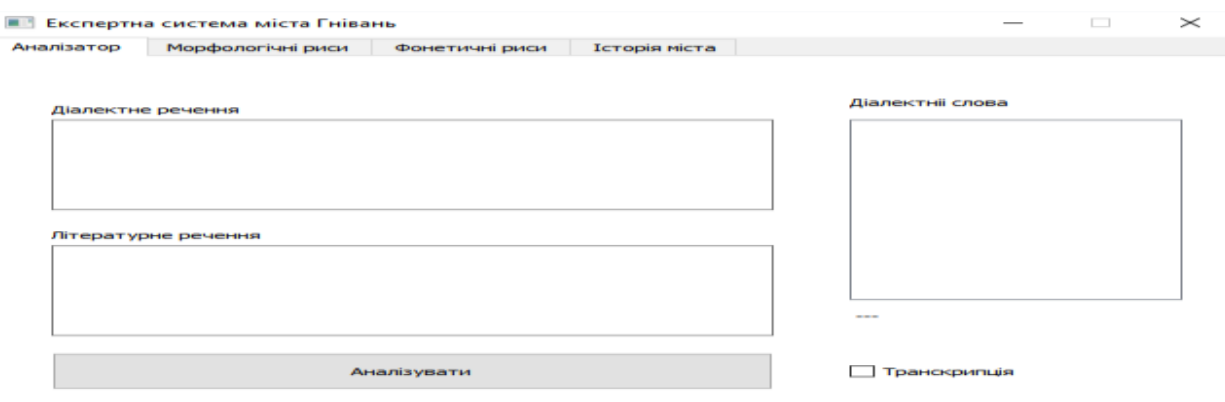

Рис. 1. Вікно експертної системи аналізу мовлення мешканців міста Гнівань 
Вкладка «Фонетичні риси» містить інформацію про фонетичні особливості говірки міста Гнівань - підсистему голосних (вокалізм) і підсистему приголосних (консонантизм) (рис. 2). Вона призначена для ознайомлення користувачів з фонетичними рисами говірки.

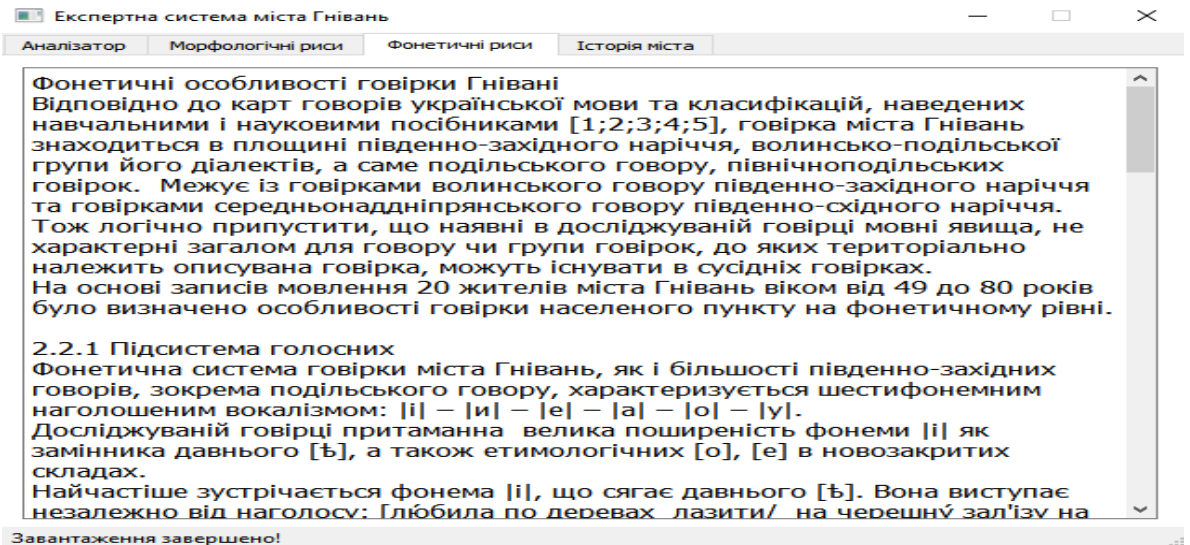

Рис. 2. Вкладка «Фонетичні риси»

Натиснувши на вкладку «Морфологічні риси», користувач побачить інформацію про морфологічні особливості говірки міста Гнівань - функціонування іменних частин мови (іменники, прикметники, займенники, числівники), уживання дієслова та його форм та особливості наголошування форм слів (рис. 3).

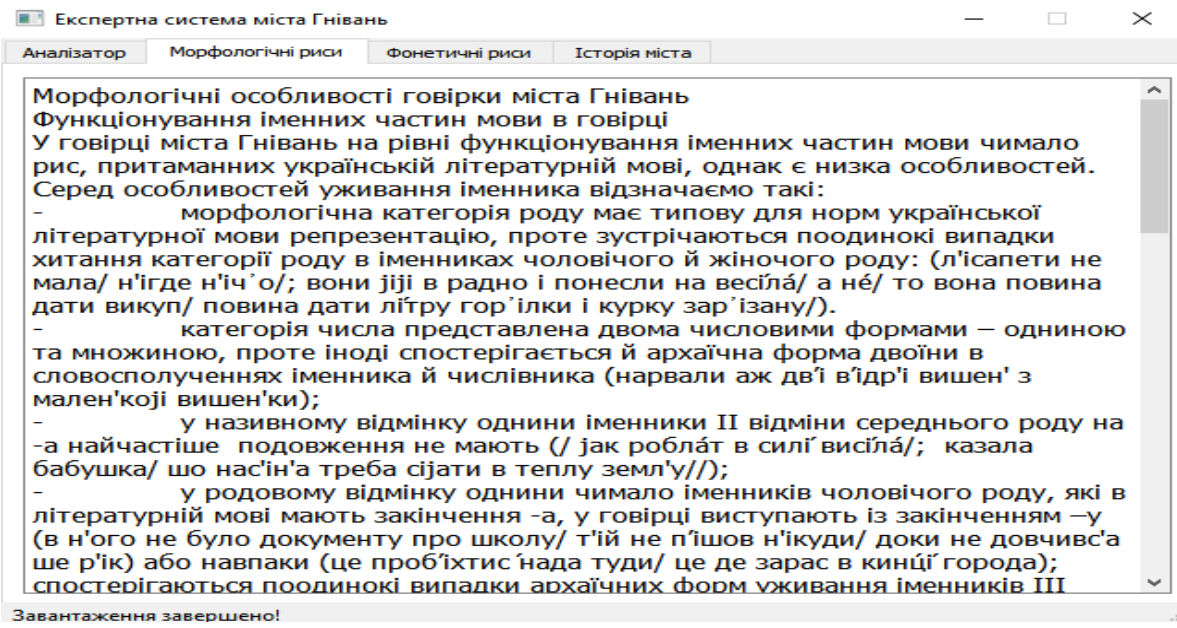

Рис. 3. Вкладка «Морфологічні риси»

Перейшовши на вкладку «Історія міста», можна дізнатися про історію міста Гнівань історію виникнення, походження назви та ін. (рис. 4).

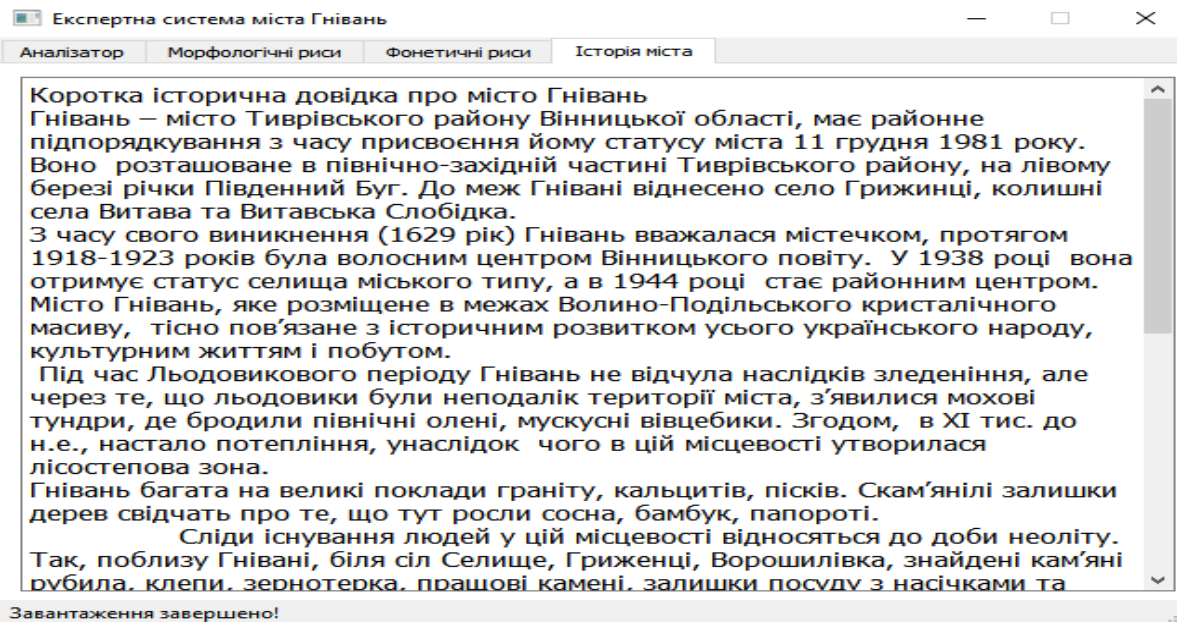

Рис. 4. Вкладка «Історія міста» 
Вкладка «Аналізатор» складається 3 таких компонентів (рис. 5):

1) Діалектне речення - текстове поле для введення затранскрибованого запису.

2) Літературне речення - текстове поле для виведення затранскрибованого запису відповідно до літературної мови.

3) Діалектні слова - перелік слів, які містяться в полі «Діалектне речення», відповідно нижче виводиться літературний відповідник обраного слова.

4) Кнопка «Аналізувати» - кнопка для активації процесу перетворення діалектного речення на речення, оформлене за правилами літературної мови.

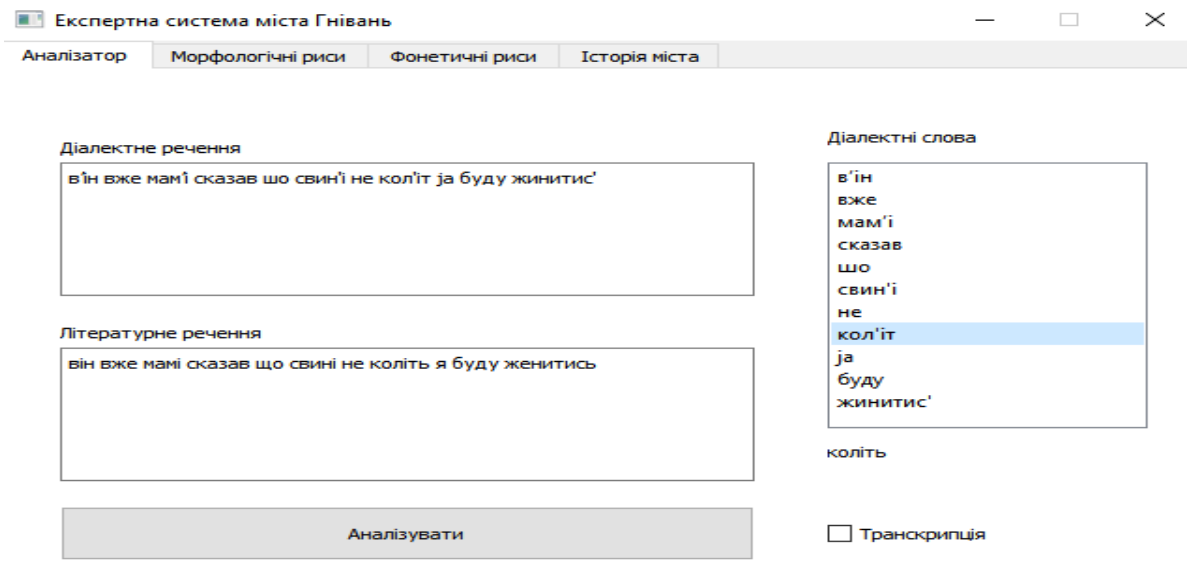

Аналіз завершено!

Рис. 5. Вкладка «Аналізатор»

Аналізатор працює у двох режимах:

- перший - виконує процес перетворення введеного діалектного речення на літературне;

- другий - перетворює літературне речення на діалектне.

Ці режими змінюються за допомогою кнопки «Транскрипція» (рис. 6).

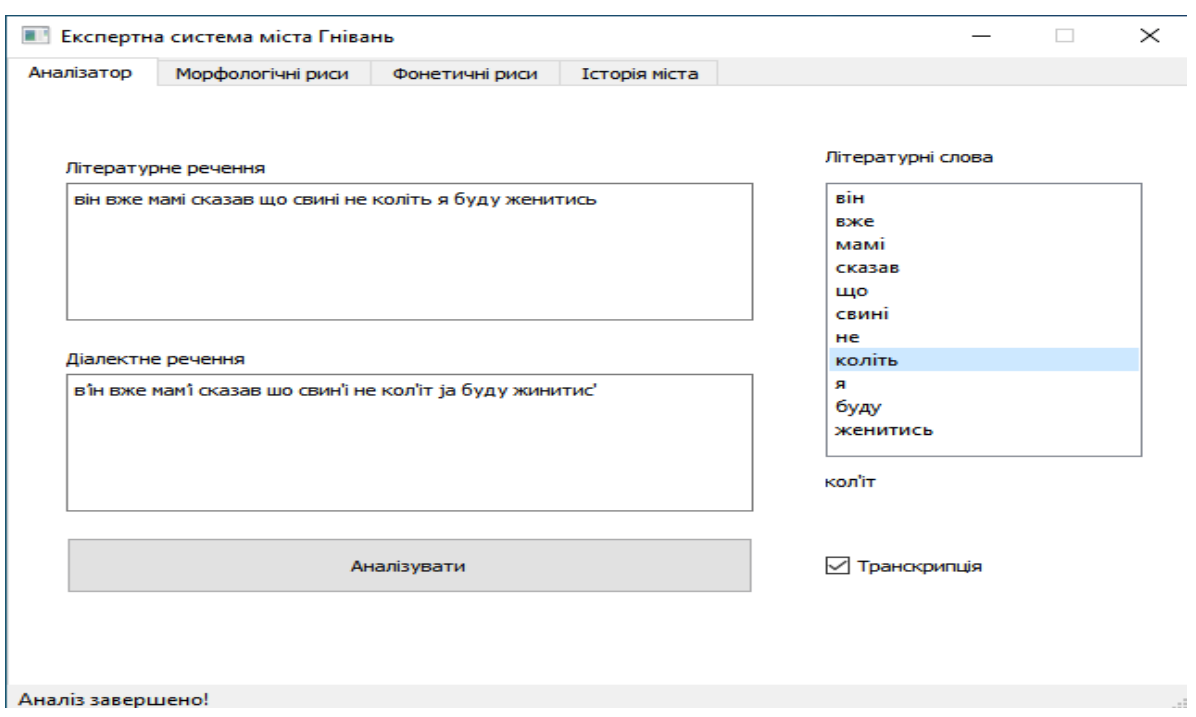

Рис. 6. Перетворення літературного речення на діалектне

Висновки та перспективи дослідження. Отже, процес створення лінгвістичної частини експертної системи аналізу мовлення мешканців міста Гнівань передбачав виділення й формалізацію фонетичних і морфологічних рис говірки, укладання словника говірки (на сьогодні налічує 2513 одиниць), що стало підгрунтям для подальшої програмної реалізації та візуалізаціï. 
Експертна система аналізу мовлення мешканців міста Гнівань складається з чотирьох частин: аналізатор (перетворює діалектне транскрибоване речення на літературне і навпаки); морфологічні риси говірки, фонетичні риси говірки, історія міста Гнівань. Створену програму можна використовувати як власне систему діалектного мовлення, довідкову систему, а також iз навчальною метою.

Розвиток експертної системи аналізу діалектного мовлення передбачає надалі поповнення бази даних лексичними одиницями, діалектними текстами говірки, додавання звукових файлів і вдосконалення структури експертної системи.

\section{Література}

Gupta, I., Nagpal, G. Artificial Intelligence and Expert Systems. Stylus Publishing, LLC, 2020.

Liebowitz, J. The Handbook of Applied Expert Systems. cRc Press, 2019.

Атлас української мови : в 3-х т (ред. І. Г. Матвіяс (голова), Я. В. Закревська та ін). Т. 1. Полісся, Наддніпрянщина і суміжні землі. Київ: Наук. думка, 1984.

[Atlas ukrayins'koyi movy : v 3-kh t (red. I. H. Matviyas (holova), Ya. V. Zakrevs'ka ta in). T. 1. Polissya, Naddnipryanshchyna i sumizhni zemli. Kyyiv: Nauk. dumka, 1984.]

Бевзенко, С. П. Українська діалектологія. Київ : Вища школа, 1980.

[Bevzenko, S. P. Ukrayins'ka dialektolohiya. Kyyiv : Vyshcha shkola, 1980.]

Вдовиченко, А. В. «До проблеми використання експертних систем у лінгвістиці». [В:] Розвиток суспільства та науки в умовах циифрової трансформації : матеріали міжнародної студентської наукової конференції, м. Одеса, 8 травня 2020 р.: Молодіжна наукова ліга, 2020. T.4. 27- 29 .

[Vdovychenko, A. V. «Do problemy vykorystannya ekspertnykh system u linhvistytsi». [V:] Rozvytok suspil'stva ta nauky v umovakh tsyfrovoyi transformatsiyi : materialy mizhnarodnoyi students'koyi naukovoyi konferentsiyi, m. Odesa, 8 travnya 2020 r.: Molodizhna naukova liha, 2020. T.4. 27-29.]

Вдовиченко, А. В. «Морфологічні особливості говірки міста Гнівань». [В:] Л. М. Коваль (ред.) Лінгвоукраїністика ХХІ століття: традииії та новаторство. Вінниця : Донецький національний університет імені Василя Стуса, 2018. Вип. 1. 120-133.

[Vdovychenko, A. V. «Morfolohichni osoblyvosti hovirky mista Hnivan'». [V:] L. M. Koval' (red.) Linhvoukrayinistyka XXI stolittya: tradytsiyi ta novatorstvo. Vinnytsya : Donets'kyy natsional'nyy universytet imeni Vasylya Stusa, 2018. Vyp. 1. 120-133.]

Вдовиченко, А. В. «Фонетичні особливості говірки міста Гнівані Вінницької області: підсистема голосних». [В:] Вісник СНТ. Вінниця, 2017. Вип. 9. 27-30.

[Vdovychenko, A. V. «Fonetychni osoblyvosti hovirky mista Hnivani Vinnyts'koyi oblasti: pidsystema holosnykh». [V:] Visnyk SNT. Vinnytsya, 2017. Vyp. 9. 27-30.]

Вдовиченко, А. В. «Фонетичні особливості говірки міста Гнівані Вінницької області: підсистема приголосних». [В:] Вісник СНТ. Вінниця, 2018. Вип. 10. 93-96.

[Vdovychenko, A. V. «Fonetychni osoblyvosti hovirky mista Hnivani Vinnyts'koyi oblasti: pidsystema pryholosnykh». [V:] Visnyk SNT. Vinnytsya, 2018. Vyp. 10. 93-96.]

Джексон, П. Введение в экспертные системы. Пер. с англ. В.Т. Тертышного. 3-е изд. Москва, Санкт-Петербург, Киев : Вильямс, 2001.

[Dzhekson, P. Vvedeniye v ekspertnyye sistemy. Per. s angl. V.T. Tertyshnogo. 3-e izd. Moskva, Sankt-Peterburg, Kiyev : Vil'yams, 2001.]

Ситар, Г., Мартинович, А. «Словник говірки як складник експертної системи аналізу мовлення мешканців міста Гнівань». [В:] Збірник наукових праџзь А'ОГОГ, 2020. 116-119.

[Sytar, H., Martynovych, A. Slovnyk hovirky yak skladnyk ekspertnoyi systemy analizu movlennya meshkantsiv mista Hnivan'. [V:] Zbirnyk naukovykh prats' $1 O H O \Sigma, 2020.116-119$.

Словник української мови в 11-ти томах. Київ: Наукова думка, 1970-1980: http://sum.in.ua/

[Slovnyk ukrayins'koyi movy v 11-ty tomakh. Kyiv: Naukova dumka, 1970-1980: http://sum.in.ua/] 
Словник української мови в 20 томах. Київ: Наукова думка:

https://services.ulif.org.ua/expl/Entry/index?wordid=1\&page $=0$

[Slovnyk ukrayins'koyi movy v 20 tomakh. Kyyiv: Naukova dumka:

https://services.ulif.org.ua/expl/Entry/index?wordid=1]

Частиков, А. П., Гаврилова, Т. А., Белов, Д. Л. Разработка экспертных систем. Среда Clips. Санкт-Петербург : «БХВ-Петербург», 2003.

[Chastikov, A. P., Gavrilova, T. A., Belov, D. L. Razrabotka ekspertnykh sistem. Sreda Clips. Sankt-Peterburg: «BKhV Peterburg», 2003.]

\section{LINGUISTIC ASPECT OF EXPERT SPEECH ANALYSIS SYSTEM FOR HNIVAN' CITY RESIDENTS: CREATION EXPERIENCE \\ Hanna Sytar, Anastasiia Martynovych \\ Department of General and Applied Linguistics and Slavonic Philology, Vasyl' Stus Donetsk National University, Vinnytsia, Ukraine}

\section{Abstract}

Background: This article is devoted to the problem of creating an expert system for analyzing dialect speech. At the present stage of development of artificial intelligence, various programs are being created for analysing the literary language. Dialect speech, which is one of the most valuable sources for studying dynamic processes in speech and features of oral speech, is still ignored by the researchers. Therefore, the creation of an expert speech analysis system for residents of Hnivan' is an important step in applying artificial intelligence approaches to the study of dialect speech.

Purpose: The aim of the study is the creation of a linguistic part of the expert system for analyzing the dialect speech of residents of the city of Hnivan'.

Results: The phonetic and morphological features of the dialect of the city of Hnivan' are identified and formalized, and the dialect dictionary is compiled (today it has 2,513 units). This became the basis for further software implementation in $\mathrm{C}++$ and the creation of a user interface using Framework QT 5.

The expert speech analysis system of Hnivan' city residents consists of four parts: the analyzer itself; phonetic features of the dialect, morphological features of the dialect, and the history of the city of Hnivan'.

Discussion: The created program can be used as a system for converting dialect transcribed speech into a recorded literary one and vice versa, a reference system, as well as for educational purposes.

The prospectives for the research are to replenish the database with the new lexical units, dialect texts of the patois, add audio files and improve the structure of the expert system.

Keywords: speech analysis, subdialect, dialect, dialect speech, expert system, applied linguistics.

\section{Vitae}

Hanna Sytar is a Doctor of Philology, Assosiate Professor, Professor of Department of General and Applied Linguistics and Slavonic Philology at Vasyl' Stus Donetsk National University. Her areas of research interests include syntax, semantics, pragmatics, construction grammar, applied linguistics.

Correspondence: h.v.sytar@donnu.edu.ua

Anastasiia Martynovych is a Master of Philology, graduate of educational program "Applied Linguistics". Her areas of research interests include dialectology, applied linguistics.

Correspondence: vdovychenko.a@donnu.edu.ua

Надійшла до редакції 20 березня 2021 року Рекомендована до друку 5 квітня 2021 року 